\title{
Psychological Behavior Change for Smartphone Addiction among University Students in Tangail, Bangladesh: An Experimental Study
}

\author{
Somaresh Kumar Mondal \\ Department of Statistics, Mawlana Bhashani Science and Technology University, \\ Santosh, Tangail-1902, Bangladesh, \\ E-mail: somaresh.mbstu11213@gmail.com \\ Mirza Nazmul Hasan \\ Department of Statistics, Shahjalal University of Science and Technology, \\ Sylhet, Bangladesh, \\ E-mail: hasan_sust_stat@yahoo.com \\ Gowranga Kumar Paul \\ Department of Statistics, Mawlana Bhashani Science and Technology University, \\ Santosh, Tangail-1902, Bangladesh, \\ E-mail: gowrangapaul@yahoo.com
}

\begin{abstract}
Objectives: This study investigated PBC for Smartphone addiction among the students of Mawlana Bhashani Science and Technology University (MBSTU) and researched whether there are statistically significant distinctions in smartphone addiction among Psychological Behavior Change (PBC) and some other variables with respect to different dimensions.
\end{abstract}

Methods: To enhance a suitable research questionnaire which be composed of with five dimensions questionnaire: excessively use of smartphone (EUS); psychosomatic-social dimension (PSD); wellbeing dimension (WD); anxiety with smartphones (AS) and high-tech dimension (HTD). A group of 520 university students, with 267 male and 253 female students, at MBSTU students was interviewed.

Results: Result showed that $42.87 \%$ participants was highly addicted in smartphone and faced PBC problem. In the basis of respective dimensions was found the statistically significant gender distinctions in the addictions of smartphone and most of time prefer in male students. There are significant differences was found by marital status which in prefer in unmarried students and use of the smartphone for greater than or equal to 4 hours in a day, by several hours of casual usage. Highest degree of smartphone addiction were found in Bachelor degree students with compare to Master's degree students. As like for the monthly earning, statistically significant distinctions in well-being conditions were set up the respondents of the lower monthly earning family.

Conclusion: $\mathrm{PBC}$ problem among University students in MBSTU are at risk of smartphones addiction; PBC phenomenon is significantly associated with negative or bad effects on daily academic life and performance.

Keywords: Keywords: Psychological behavior change (PBC); Students; Smartphones; Addiction; Dimension; Likert scale.

DOI: $10.7176 / J S T R / 6-13-08$

\section{Introduction}

Now-a-days high-tech communication path has increased rapidly all aspects in modern existence. Smartphone is one of them for offering a special types of applications and quickly allow to different

$\mathbf{5 7} \mid \mathrm{P}$ a g e

www.iiste.org 
social media, gaming platform by the aid of internet connection (Scherer, 1997; Kraut et al., 1998). Meanwhile teenagers use smartphone for communicated with friends, sharing information but older persons use smartphone for taking with her/his closer persons(Cha \& Seo, 2018). On the other side, with the help of smartphone network the whole world is connected with each other (with family members, friends and clients). Smartphones and Social media such as Facebook, Twitter, LinkedIn, YouTube, Instagram, WhatsApp, Viber etc. connect online more and more people (Abo-Jedi, 2008).

According to Groupe Speciale Mobile Association (GSMA) 2014, half of the world's population has adoption smartphone for daily work. In whole world 1.85 billion people were used smartphone in 2014 but this rate is dramatically expected to be 2.32 billion to 2.87 billion from 2017 to 2020 (Statista, 2017). Pew research center (2015) reported that 21 developing nations (median of 54\%) use smartphone internet occasionally with compare in 11 developed and powerful economics nations (median of 87\%). A Korean survey result (2016), 83.6\% Korean were used smartphone whose average age over 3 years and overall $86.7 \%$ males, 80.6\% females and 95.9\% adolescents who are badly addicted smartphone (Korea Internet and Security Agency, 2017). On the annual report of Bangladesh Telecoms (2016) 60 million people were used smartphone internet among them $35 \%$ are teenagers.

According to American physician Ivan Goldberg (1996) Technology addiction first comes from the internet addiction then Young (1996) published a scientific research paper on internet addiction. Internet habituation is commonly described as an own kingdom where a person lost total resistor of use internet completely and internet to a point where he involvements problematic consequences that negatively affect his life (Young \& Abreu, 2011). A Smartphone introduce more technology equipment and single utilizer dependent more on it that makes lots of problems (Hong, Chiu, \& Huang, 2012).

Between university students has negative outcomes of smartphone addiction (Al-Barashdi et al., 2015). Most of the varsity students use smartphone in classrooms (Tindell and Bohlander, 2012) and between university students and smartphone use has negative relation (Chen \& Lever, 2004; Lepp, Barkle, \& Karpinski, 2015). Smartphone usage respondents belongs to a positive inter-relationship with anxiety and a negative relationship with self-esteem (Hong et al., 2012). Student's excessively use of smartphone have negative effects on their academic performance (Ishii, 2010) and also impose negatively impact on psychosomatic problem on well-being, and subjective happiness or gladness (Lepp, Barkle, and Karpinski, 2014). A study reveals that in male users, unmarried users as well as high income users has a significant differences and several negative effects on social and family life of users (Assabawy, 2006).

Finally, with the help of scientific research work of smartphone addiction and this study want to find out the relationship between several variables and its dimension effects on Mawlana Bhashani Science and Technology University students. In addition, the prime objective of the present study is to identify the bad effect of smartphone on university student's academic performance, psychology, behavior, well-being and social.

\section{Material and methods}

\subsection{Participants}

To collect the suitable variables for this research problem, descriptive research method was implement. The study population was the university student who used smartphones and presented oneself at MBSTU campus in Bachelor and Master's program. A total number of 520 university students take part in this study.

\subsection{Questionnaire}

To exhibited smartphone addiction related suitable questionnaire implanted different scientific research questionnaire and literature review (Aljomaa et al., 2016, Kwon et al., 2013; Alasdair \& Philips, 2011; Young \& de Abreu, 2011; Abo-Jedi, 2008; Torrecillas, 2007; Walsh \& White, 2007; Campbell, 2005; Young, 1998;). Then the questionnaire is divided into different dimensions but 80 cases were include in the questionnaire, now which questionnaire separated under 5 dimensions. To set up this dimensions with the help of theoretical knowledge, literature review ((Heron \& Shapira, 2004) and the description of internet addiction manual (DSM IV) (American Psychiatric Association, 2013, 1994; Castillo et al., 2007). The 80 cases presented in five dimensions such as EUS (11 cases), HTD (13 cases), PSD (25 cases), AS (17 cases), and, WD (14 csaes). To identify the interior correlation of this survey was

58 | P a g e

www.iiste.org 
compute correlation (Aljomaa et al. 2016) between (i) items and five dimensions be affiliated to the correlation coefficients fluctuated from 0.74 to 0.95 , (ii) items and the whole questionnaire be affiliated to the correlation coefficients fluctuated from 0.69 to 0.94 and (iii) dimensions belong to the correlation coefficients fluctuated from 0.71 to 0.89 . All fluctuated correlations were statistically significant.

\subsection{Data collection procedures}

A 5 point Likert scale used to measured score which ranging from 1 ("never or almost never true of me") to 5 ("always or almost always true of me") based on researcher recommendation scoring method(Aljomaa et al. 2016; Abo-Jedi, 2008; Al-Jamal, 2014; Torrecillas, 2007). On the basis of a 5 point Likert scale 400 is the highest score and 80 is the lowest score on this questionnaire. The median was help to identify the respondent are smartphone addicts or not, whose score be situated greater than the median to be considered smartphone addicts. For example, $+1,+2,+3,+4,+5$ are the rating points and suppose that a case +3 is rating point and 84 is the score then the multiplied the rating and score is 240 and greater are as well thought-out smartphone addicts.

\subsection{Data analysis}

Statistical Package for Social Sciences (SPSS) software were used to analyze the data. Descriptive statistics were used to justify the answer to the research question one and two. For justification of the research question third, fourth and fifth were usually used to independent t-test. At last one-way analysis of variance (ANOVA) and Bonferroni test were used to justify the research question sixth and seventh with the help of significances means differences,

\section{Result and Discussion}

Table 1 displays the frequency distribution of university students according to variables. The median is used to answer first question which participants are addict smartphone. Based on this criteria 308 respondents out of the 520 cohort respondents were classified as smartphone addicts (59.23\%).

Table 1: The frequency distribution of university students according to variables.

\begin{tabular}{lccc}
\hline Variable & Levels & Frequency & Percentage \\
\hline Gender & Males & 267 & 51.35 \\
& Females & 253 & 48.65 \\
Marital status & Unmarried & 433 & 83.27 \\
Educational qualification & Married & 87 & 16.73 \\
& Bachelor & 406 & 78.08 \\
Family monthly earning (tk) & Master's & 114 & 21.92 \\
& $\leq 20,000$ & 167 & 32.12 \\
& $21,000-30,000$ & 240 & 46.15 \\
Casual usage hours & $\geq 30,000$ & 113 & 21.73 \\
& $\leq 2$ hours & 30 & 5.77 \\
& $2-4$ hours & 153 & 29.42 \\
& $\geq 4$ hours & 337 & 64.81 \\
\hline
\end{tabular}

To answer the second inquiry were computed participants mean and standard deviation. Table 2 shows mean, standard deviation and questionnaire order (based on means). Table 2 represents the excessively use of smartphone mean (M) is 3.11 and standard deviation (SD) is 0.76 , the psychosomatic-social dimension $(\mathrm{M}=3.04 ; \mathrm{SD}=0.79)$, the well-being dimension $(\mathrm{M}=2.93 ; \mathrm{SD}=0.84)$, anxiety with smartphones $(\mathrm{M}=2.76 ; \mathrm{SD}=0.71)$, and the high-tech dimension $(\mathrm{M}=2.99 ; \mathrm{SD}=0.80)$. The overall mean of the questionnaire was 2.87 and standard deviation was 0.74 . 
Table 2: Means, standard deviations (SD) and order of dimensions of the smartphone addiction questionnaire.

\begin{tabular}{lllll}
\hline Number & Order & Dimension & Mean & SD \\
\hline 1 & 1 & Excessively use of smartphone & 3.11 & 0.76 \\
2 & 2 & Psychosomatic-social dimension & 3.07 & 0.79 \\
3 & 3 & Well-being dimension & 2.93 & 0.84 \\
4 & 4 & Anxiety with smartphones & 2.76 & 0.71 \\
5 & 5 & High-tech dimension & 2.99 & 0.80 \\
\multicolumn{2}{l}{ The Whole } & research Questionnaire & 2.87 & 0.74 \\
\hline
\end{tabular}

To answer the inquiry of survey question need mean, standard deviation (SD) and independent samples t-test which examine the smartphone addiction by gender. Table 3 illustrations this descriptive statistics. From table 3 declares that all the dimension of whole questionnaire are statistically significant (Pvalue $<0.05$ ) by gender differences in addiction of smartphone and all dimensions males in abetment. The mean scores of male respondents were greater than individuals of female respondents on smartphone excessively use $(\mathrm{M}=32.18$ vs. $30.25 ; \mathrm{t}$ - value $=3.141)$, the psychosomatic-social dimension $(\mathrm{M}=77.12$ vs. 71.26 ; $\mathrm{t}-$ value $=3.231)$, the well-being dimension $(\mathrm{M}=40.12$ vs. 36.23 ; $\mathrm{t}$ value $=3.812)$, anxiety with smartphones $(M=53.45$ vs. 49.65 ; $\mathrm{t}$ - value $=3.391)$, high-tech dimension $(\mathrm{M}=41.26$ vs. $38.25 ; \mathrm{t}$ - value $=3.481)$ and the whole survey questionnaire $(\mathrm{M}=3.214$ vs. $2.984 ; \mathrm{t}$ value $=3.520$ ). No significant distinctions was set up between males as well as females on the hightech dimension.

Table 3: The values of t-test for the statistically significant distinctions in smartphone addiction by gender of university students.

\begin{tabular}{|c|c|c|c|c|c|c|}
\hline Dimension & Gender & Frequency & Mean & SD & t-value & Sig. \\
\hline \multirow{2}{*}{ Excessively use of smartphone } & Males & 267 & 32.18 & 7.12 & \multirow{2}{*}{3.141} & \multirow{2}{*}{$0.002 *$} \\
\hline & Females & 253 & 30.25 & 6.89 & & \\
\hline \multirow{2}{*}{ Psychosomatic-social dimension } & Males & 267 & 77.12 & 22.15 & \multirow[b]{2}{*}{3.231} & \multirow{2}{*}{$0.001^{*}$} \\
\hline & Females & 253 & 71.26 & 19.17 & & \\
\hline \multirow{2}{*}{ Well-being dimension } & Males & 267 & 40.12 & 12.02 & \multirow[b]{2}{*}{3.812} & \multirow{2}{*}{$0.000^{*}$} \\
\hline & Females & 253 & 36.23 & 11.25 & & \\
\hline \multirow{2}{*}{ Anxiety with smartphones } & Females & 267 & 53.45 & 13.65 & \multirow[t]{2}{*}{3.391} & \multirow[t]{2}{*}{$0.000^{*}$} \\
\hline & Males & 253 & 49.65 & 11.89 & & \\
\hline \multirow{2}{*}{ High-tech dimension } & Males & 267 & 41.26 & 10.75 & \multirow[t]{2}{*}{3.481} & \multirow[t]{2}{*}{$0.000^{*}$} \\
\hline & Females & 253 & 38.25 & 8.95 & & \\
\hline \multirow{2}{*}{ The Whole research Questionnaire } & Males & 267 & 3.214 & 0.78 & \multirow[t]{2}{*}{3.520} & \multirow[t]{2}{*}{$0.000^{*}$} \\
\hline & Females & 253 & 2.984 & 0.71 & & \\
\hline
\end{tabular}

To answer the inquiry question to need computed mean (M), standard deviation (SD) and t-test in order to examine distinctions in addiction of smartphone by marital status. Table 4 appearances this descriptive statistics. Now data in Table 4, says that all the dimension of whole questionnaire are statistically significant $(\mathrm{P}-$ value $<0.05$ ) by social status differences in addiction of smartphone and all dimensions males in abetment. Unmarried participants overtook married participants proceeding excessively use $(\mathrm{M}=36.35$ vs. 33.26 ; $\mathrm{t}$ - value $=3.307)$, the psychosomatic-social dimension $(\mathrm{M}=$ 76.41 vs. 68.32 ; $\mathrm{t}$ - value $=3.108)$, anxiety with smartphones $(\mathrm{M}=51.27$ vs. 46.62 ; $\mathrm{t}$ - value $=3.308)$, the high-tech dimension $(\mathrm{M}=44.61$ vs. 37.65 ; $\mathrm{t}$ - value $=3.829)$, well-being dimension $(\mathrm{M}=36.21$ vs. 31.21 ; $\mathrm{t}$ - value $=3.405)$ and the whole survey questionnaire $(\mathrm{M}=3.24$ vs. 2.96 ; $\mathrm{t}$ - value $=3.623)$. 
Table 4: The values of t-test for the statistically significant distinctions in smartphone addiction by the marital status of university students.

\begin{tabular}{|c|c|c|c|c|c|c|}
\hline Dimension & $\begin{array}{c}\text { Marital } \\
\text { status }\end{array}$ & Frequency & Mean & SD & t-value & Sig \\
\hline \multirow[t]{2}{*}{ Excessively use of smartphone } & Unmarried & 433 & 36.45 & 8.65 & \multirow{2}{*}{3.307} & \multirow{2}{*}{$0.001^{*}$} \\
\hline & Married & 87 & 33.26 & 8.12 & & \\
\hline \multirow[t]{2}{*}{ Psychosomatic-social dimension } & Unmarried & 433 & 76.41 & 23.64 & \multirow{2}{*}{3.108} & \multirow{2}{*}{$0.002 *$} \\
\hline & Married & 87 & 68.32 & 21.84 & & \\
\hline \multirow[t]{2}{*}{ Well-being dimension } & Unmarried & 433 & 36.21 & 13.25 & \multirow{2}{*}{3.405} & \multirow{2}{*}{$0.000 *$} \\
\hline & Married & 87 & 31.21 & 12.34 & & \\
\hline \multirow[t]{2}{*}{ Anxiety with smartphones } & Unmarried & 433 & 51.27 & 12.14 & \multirow{2}{*}{3.308} & \multirow{2}{*}{$0.001 *$} \\
\hline & Married & 87 & 46.62 & 11.93 & & \\
\hline \multirow[t]{2}{*}{ High-tech dimension } & Unmarried & 433 & 44.61 & 16.21 & \multirow{2}{*}{3.829} & \multirow{2}{*}{$0.000 *$} \\
\hline & Married & 87 & 37.65 & 15.32 & & \\
\hline \multirow[t]{2}{*}{ The Whole research Questionnaire } & Unmarried & 433 & 3.24 & 0.74 & \multirow{2}{*}{3.623} & \multirow{2}{*}{$0.000 *$} \\
\hline & Married & 87 & 2.96 & 0.64 & & \\
\hline
\end{tabular}

To answer the inquiry question need mean (M), standard deviation (SD) and independent samples t-test which examine the smartphone addiction by educational qualification. Table 5 illustrations this descriptive statistics. As exposed data in Table 5, respondents in a bachelor degree program students out sail respondents in a graduate degree program students for addiction of smartphone on the whole survey questionnaire and its five dimensions. The overall mean scores for smartphone excessively use $(\mathrm{M}=36.16$ vs. 32.65 ; $\mathrm{t}-$ value $=3.679)$, the psychosomatic-social dimension $(\mathrm{M}=75.34$ vs. 69.12 ; $\mathrm{t}$ value $=3.058)$, the well-being dimension $(\mathrm{M}=39.23$ vs. $34.52 ; \mathrm{t}$ - value $=3.223)$, anxiety with smartphones $(\mathrm{M}=50.21$ vs. $45.42 ; \mathrm{t}$ - value $=3.3 .548)$, the high-tech dimension $(\mathrm{M}=41.65$ vs. 38.21 ; $\mathrm{t}$ - value $=3.394)$, and the whole survey questionnaire $(\mathrm{M}=2.98$ vs. $2.70 ; \mathrm{t}$ - value $=3.742)$ which are statistically significant at 5\% level of significant.

Table 5: The values of t-test for the statistically significant distinctions in smartphone addiction by the educational qualification of university students.

\begin{tabular}{|c|c|c|c|c|c|c|}
\hline Dimension & $\begin{array}{l}\text { Educational } \\
\text { qualification }\end{array}$ & Frequency & Mean & SD & t-value & Sig \\
\hline \multirow[t]{2}{*}{ Excessively use of smartphone } & Bachelor & 406 & 36.16 & 9.21 & \multirow{2}{*}{3.679} & \multirow{2}{*}{$0.000 *$} \\
\hline & Master's & 114 & 32.65 & 8.94 & & \\
\hline \multirow[t]{2}{*}{ Psychosomatic-social dimension } & Bachelor & 406 & 75.34 & 21.05 & \multirow{2}{*}{3.058} & \multirow{2}{*}{$0.002 *$} \\
\hline & Master's & 114 & 69.12 & 18.63 & & \\
\hline \multirow[t]{2}{*}{ Well-being dimension } & Bachelor & 406 & 39.23 & 14.23 & \multirow{2}{*}{3.223} & \multirow{2}{*}{$0.001 *$} \\
\hline & Master's & 114 & 34.52 & 13.66 & & \\
\hline \multirow[t]{2}{*}{ Anxiety with smartphones } & Bachelor & 406 & 50.21 & 13.14 & \multirow{2}{*}{3.548} & \multirow{2}{*}{$0.000 *$} \\
\hline & Master's & 114 & 45.42 & 12.62 & & \\
\hline \multirow[t]{2}{*}{ High-tech dimension } & Bachelor & 406 & 41.65 & 10.25 & \multirow{2}{*}{3.394} & \multirow{2}{*}{$0.000 *$} \\
\hline & Master's & 114 & 38.21 & 9.36 & & \\
\hline \multirow[t]{2}{*}{ The Whole research Questionnaire } & Bachelor & 406 & 2.98 & 0.76 & \multirow{2}{*}{3.742} & \multirow{2}{*}{$0.000 *$} \\
\hline & Master's & 114 & 2.70 & 0.69 & & \\
\hline
\end{tabular}

To answer the sixth inquiry, ANOVA was need to construct exploring distinctions in smartphone addiction by hours of casual usage. This records is revealed in Table 6 . Now Table 6 shows to determine the statistical significance distinctions in smartphone addiction by the casual usage hours of smartphone in a day was used Bonferroni test. Table 7 represents these vital findings in this study. Since table 7 said that there existed statistically significant distinctions founded by casual usage hours

$61 \mid \mathrm{P}$ a g e

www.iiste.org 
in smartphone. Smartphone addiction was very high in the respondents that use smartphone greater than or equal to 4 hours in a day. This method applied to whole survey questionnaire and all five dimensions. The total mean scores for five dimensions and the whole survey questionnaire are 38.47, $80.28,39.81,52.96,44.58$, and 3.174. That means the mean of greater than or equal to 4 hours is higher than the mean of less than 2 hours of use a day time and beginning 2 to 4 hours of smartphone use in a day time. On the other hand less than 2 hours and from 2 to 4 hours are found statistically significant differences categories on the dimensions of "smartphone excessively use" ( $\mathrm{M}=32.45$ vs. 28.04) and "the high-tech dimension" ( $\mathrm{M}=37.94$ vs. 33.53) in abetment of from 2 to 4 hours smartphone use per day category.

Table 6: ANOVA table for the statistically significant distinctions in smartphone addiction by the of casual usage hours of university students.

\begin{tabular}{lcccccc}
\hline Dimension & Source & df & $\begin{array}{c}\text { Sum of } \\
\text { Squares }\end{array}$ & $\begin{array}{c}\text { Mean } \\
\text { squares }\end{array}$ & F-value & P-value \\
\hline \multirow{4}{*}{ Excessively use of smartphone } & Factor & 2 & 6421.324 & 3210.662 & 57.327599 & $0.000^{*}$ \\
& Error & 517 & 28954.854 & 56.00552 & & \\
& Total & 519 & 35376.178 & & & \\
& Factor & 2 & 21074.461 & 10537.231 & 28.471487 & $0.000^{*}$ \\
Psychosomatic-social dimension & Error & 517 & 191340.48 & 370.09765 & & \\
& Total & 519 & 212414.94 & & & \\
Well-being dimension & Factor & 2 & 3852.426 & 1926.213 & 25.225039 & $0.000^{*}$ \\
& Error & 517 & 39478.715 & 76.361151 & & \\
& Total & 519 & 43331.141 & & & \\
Anxiety with smartphones & Factor & 2 & 7814.529 & 3907.2645 & 25.306271 & $0.000^{*}$ \\
& Error & 517 & 79824.315 & 154.39906 & & \\
& Total & 519 & 87638.844 & & & \\
High-tech dimension & Factor & 2 & 5812.759 & 2906.3795 & 33.23255 & $0.000^{*}$ \\
& Error & 517 & 45214.653 & 87.455809 & & \\
& Total & 519 & 51027.412 & & & \\
The Whole research Questionnaire & Factor & 2 & 30.26 & 15.13 & 31.876645 & $0.000^{*}$ \\
& Error & 517 & 245.39 & 0.4746422 & & \\
& Total & 519 & 275.65 & & & \\
\hline
\end{tabular}


Table 7: Bonferroni test values for the statistically significant distinctions in smartphone addiction by the casual usage hours of university students.

\begin{tabular}{lccccc}
\hline Dimension & $\begin{array}{c}\text { Casual usage } \\
\text { hours }\end{array}$ & Mean & $\begin{array}{c}\leq 2 \\
\text { hours }\end{array}$ & 2c- 4 hours & $\geq 4$ hours \\
\hline Excessively use of smartphone & $\leq 2$ hours & 28.04 & - & $4.712^{*}$ & $11.697^{*}$ \\
& $2-4$ hours & 32.45 & - & - & $5.478^{*}$ \\
& $\geq 4$ hours & 38.47 & - & - & - \\
Psychosomatic-social dimension & $\leq 2$ hours & 57.25 & - & $10.075^{*}$ & $21.457^{*}$ \\
& $2-4$ hours & 69.58 & - & - & $12.147^{*}$ \\
Well-being dimension & $\geq 4$ hours & 80.25 & - & - & - \\
& $\leq 2$ hours & 30.67 & - & $0.873^{*}$ & $5.124^{*}$ \\
Anxiety with smartphones & $2-4$ hours & 33.86 & - & - & $4.973^{*}$ \\
& $\geq 4$ hours & 39.81 & - & - & - \\
& $\leq 2$ hours & 40.27 & - & $6.214^{*}$ & $13.978^{*}$ \\
High-tech dimension & $2-4$ hours & 45.37 & - & - & $8.236^{*}$ \\
& $\geq 4$ hours & 52.96 & - & - & - \\
& $\leq 2$ hours & 33.53 & - & $6.497^{*}$ & $11.854^{*}$ \\
& $2-4$ hours & 37.94 & - & - & $8.369^{*}$
\end{tabular}

To answer the seventh inquiry, ANOVA was need to construct exploring distinctions in smartphone addiction by monthly earnings. This data is presented by Table 8 . In Table 8 shows to determine the statistically significance distinctions in smartphone addiction by monthly earnings. Bonferroni test was implemented to find the statistically significant distinctions in smartphone addiction by monthly earning of university students. 
Table 8: ANOVA table for the statistically significant distinctions in smartphone addiction by monthly earning of university students.

\begin{tabular}{|c|c|c|c|c|c|c|}
\hline Dimension & Source & df & $\begin{array}{l}\text { Sum of } \\
\text { Squares }\end{array}$ & $\begin{array}{c}\text { Mean } \\
\text { squares }\end{array}$ & F-value & P- value \\
\hline \multirow{3}{*}{ Excessively use of smartphone } & Factor & 2 & 29.365 & 14.683 & 0.231 & 0.284 \\
\hline & Error & 516 & 32694.653 & 63.362 & & \\
\hline & Total & 518 & 32724.018 & & & \\
\hline \multirow{3}{*}{ Psychosomatic-social dimension } & Factor & 2 & 756.325 & 378.163 & 0.958 & 0.107 \\
\hline & Error & 516 & 203654.851 & 394.681 & & \\
\hline & Total & 518 & 204411.181 & & & \\
\hline \multirow{3}{*}{ Well-being dimension } & Factor & 2 & 1623.321 & 811.661 & 6.434 & $0.001 *$ \\
\hline & Error & 516 & 65089.214 & 126.142 & & \\
\hline & Total & 518 & 66712.535 & & & \\
\hline \multirow{3}{*}{ Anxiety with smartphones } & Factor & 2 & 284.259 & 142.131 & 0.901 & 0.098 \\
\hline & Error & 516 & 81365.257 & 157.685 & & \\
\hline & Total & 518 & 81649.516 & & & \\
\hline \multirow{3}{*}{ High-tech dimension } & Factor & 2 & 217.361 & 108.681 & 1.239 & 0.127 \\
\hline & Error & 516 & 45263.842 & 87.721 & & \\
\hline & Total & 518 & 45481.2 & & & \\
\hline \multirow{3}{*}{ The Whole research Questionnaire } & Factor & 2 & 1.694 & 0.847 & 1.341 & $0.000^{*}$ \\
\hline & Error & 516 & 326.273 & 0.632 & & \\
\hline & Total & 518 & 327.967 & & & \\
\hline
\end{tabular}

\section{Conclusion}

This study analysis the trends of smartphone addiction in Mawlana Bhashani Science and Technology University and try to find out the statistically significance differences in smartphone addiction based on different variable and their dimensions. Results showed that $59.23 \%$ university students are addicted to smartphone. This result is more serious compare to the study result of King Saud University student's smartphone addiction (Aljomaa et al. 2016). However, this percentages is corresponding to international journal paper (Szpakow et al., 2011; Abo-Jedi, 2008; Wajcman et al., 2007; Torrecillas, 2007). This study also reveal that EUS, PSD, WD, AS and HTD were most statistically significant factors of smartphone addiction. This university students have more depend on smart hope to do their daily work. For this reason they have excessively use of smartphone and more addicted to smartphone. The overdependence of smartphone can negative reflect in students physical, psychosomatic, social, marital and educational activities. This findings is proved in furthermost scientific research on smartphone addiction (Aljomaa et al. 2016; Samaha \& Hawi, 2016; ; Lepp et al., 2014; AboArrab \& Al-Qosairi, 2014; Javid et al., 2011; GSMA, 2011; Campbell, 2005;). Gender were a most importance factor in this study and all the dimensions were set up in good turn of male students. That means males students use smartphone greater than females students and they are more addicted of smartphone. This finding is match with the scientific studies of Aljomaa et al., 2016; Samaha \& Hawi, 2016; Choliz, 2012; and Walsh et al., 2011). This study reveals that marital status mostly influenced smartphone addiction as well as married participants scored lower than unmarried participants on whole research questionnaire and all five dimensions. This study able to find out a statistically significant relation between educational level and smartphone addiction, MS program students scored significantly lower than bachelor program students on the whole questionnaire and all dimensions. This finding specifies

64 | P a g e

www.iiste.org 
that bachelor degree program students (say as young people) were more likely to addicted smartphone than MS degree program students (say as adults). This result is similar that adolescents students age are more addicted than references age groups (Maya \& Nizar, 2016; Divan et al., 2012; Attamimi, 2011; Hatch, 2011; Ishii, 2010; Wajcman et al., 2007; and International Telecommunication Union (ITU), 2004). Analysis indicated that statistically significant distinctions in addiction of smartphone in the whole research questionnaire and all the five dimensions who oneself use smartphones greater than or equal to 4 hours in a day time. Several scientific research reported that who use smartphones extensive time periods are more likely to be smartphone addicts (Attamimi, 2011; Ishii, 2010; Abo-Jedi, 2008; Torrecillas, 2007; and Richard, 2001). In well-being dimension university students with a monthly earning lower than 10,000 tk scored greater than other binary income categories and they were more attack negative on well-being effects in smartphone addiction.

\section{Authors' contributions}

Experimental Design and Study: Mondal SK, Paul GK; Literature research: Hasan MN, Paul GK; Figure and table preparation: Paul GK, Mondal SK; Manuscript writing and proofreading: Mondal SK, Hasan MN, Paul GK and All authors read and approved the final manuscript.

\section{Funding}

Not applicable.

\section{Availability of data and materials}

Not applicable.

\section{Consent for publication}

Not applicable.

\section{Conflict of Interest}

There is no conflict of interest.

\section{Competing interests}

The authors declare that they have no potential conflicts of interest.

\section{Reference}

Aljomaa, S. S., Qudah, M. F. A., Albursan, I. S., Bakhiet, S. F., \& Abduljabbar, A. S. (2016). Smartphone addiction among university students in the light of some variables. Computers in Human Behavior, 61, 155-164.

Al-Barashdi, H. S., Bouazza, A., \& Jabur, N. H. (2015). Smartphone addiction among university undergraduates: a literature review. Journal of Scientific Research and Reports, 210-225.

American Psychiatric Association. (2013). Diagnostic and statistical manual of mental disorders (DSM-5®). American Psychiatric Pub.

Alasdair, A., \& Philips, J. (2011). Children and mobile phones. The content of this Article can be freely used with appropriate citation www. powerwatch. org. uk or www. emfields. org. P1-8.

Attamimi, A. (2011). The reasons for the prevalence of BlackBerry cellphones and the resulting educational effects from the perspective of secondary school students in Abo-Dhabi. In Conference on the negative effects of cellphones on secondary school students, UAE (pp. 105130).

Abo-Jedi, A. (2008). Cellphone addiction and its relation to self-closure in a sample of Jordanian university and Amman private university students. The Jordanian Journal for Educational Sciences, 4, 137-150. 
Assabawy, H. (2006). Social effects of cellphones (a field study in Mosul City). Mosulian Studies, $14,77-105$.

American Psychiatric Association. (1994). Diagnostic and statistical manual of mental disorders (DSM IV) (4th Ed.) Washington, DC.

Chóliz, M. (2012). Mobile-phone addiction in adolescence: the test of mobile phone dependence (TMD). Progress in Well-being Sciences, 2(1), 33-44.

Castillo, R. J., Carlat, D. J., Millon, T., Millon, C. M., Meagher, S., Grossman, S., \& American Psychiatric Association. (2007). Diagnostic and statistical manual of mental disorders. American Psychiatric Association Press, Washington, DC.

Campbell, M. A. (2005). The impact of the mobile phone on young people's social life.

Chen, Y. F., \& Lever, K. M. (2005). Relationships among mobile phones, social networks, and academic achievement: A comparison of US and Taiwanese college students. In meeting of the Hungarian Academy of Sciences Conference. Budapest, Hungary.

Divan, H. A., Kheifets, L., Obel, C., \& Olsen, J. (2012). Cell phone use and behavioural problems in young children. J Epidemiol Community Well-being, 66(6), 524-529.

Groupe Speciale Mobile Association. (2015). State of the industry report: Mobile money. London: GSMA.

Goundar, S. (2012). Cloud Computing: Understanding the Technology before Getting "Clouded". In Recent Progress in Data Engineering and Internet Technology (pp. 217-222). Springer, Berlin, Heidelberg.

Goldberg, I. (1996). Internet addiction disorder.

Hong, F. Y., Chiu, S. I., \& Huang, D. H. (2012). A model of the relationship between psychosomatic characteristics, mobile phone addiction and use of mobile phones by Taiwanese university female students. Computers in Human Behavior, 28(6), 2152-2159.

International Telecommunication Union. (2004). African telecommunication indicators. Telecommunications Development Bureau, International Telecommunication Union.

Ishii, K. (2011). Examining the adverse effects of mobile phone use among Japanese adolescents. Keio Communication Review, 33(33), 69-83.

Javid, M., Malik, M. A., \& Gujjar, A. A. (2011). Mobile Phone Culture and its Psychosomatic Impacts on Students' Learning at the University Level. Language in India, 11(2).

Kraut R, Patterson M, Lundmark V, et al. (1998) Internet paradox: A social technology that reduces social involvement and psychological well-being? American Psychologist 53: 1011-1031

Kwon, M., Lee, J. Y. K., Won, W. Y., Park, J. W., Min, J. A., Hahn, C., .. \& Kim, D. J. (2013). Development and Validation of a Smartphone Addiction Scale (SAS). Copyright: Creative Commons License.

Korea Internet and Security Agency (2017) 2016 Survey on Internet Usage. Seoul: Korea Internet and Security Agency 
Lepp, A., Barkley, J. E., \& Karpinski, A. C. (2014). The relationship between cell phone use, academic performance, anxiety, and satisfaction with life in college students. Computers in Human Behavior, 31, 343-350.

Pew Research Center (2016) Smartphone ownership and internet usage continues to climb in emerging economies. Available at: http://www.pewglobal.org/2016/02/22/smartphoneownership-and-internet-usage-continues-to-climb-in-emergingeconomies/

Qudah, M. F. A., Albursan, I. S., Bakhiet, S. F. A., Hassan, E. M. A. H., Alfnan, A. A., Aljomaa, S. S., \& AL-khadher, M. M. A. (2019). Smartphone Addiction and Its Relationship with Cyberbullying Among University Students. International Journal of Mental Well-being and Addiction, 17(3), 628-643.

Richard, A. (2001). Internet addiction.

Statista (2017) Number of smartphone users worldwide from 2014 to 2020. Available at: https://www.statista.com/statistics/330695/number-of-smartphone-users-worldwide/

Samaha, M., \& Hawi, N. S. (2016). Relationships among smartphone addiction, stress, academic performance, and satisfaction with life. Computers in Human Behavior, 57, 321-325.

Samaha, M., \& Hawi, N. S. (2016). Relationships among smartphone addiction, stress, academic performance, and satisfaction with life. Computers in Human Behavior, 57, 321-325.

Scherer K (1997) College life online: Healthy and unhealthy Internet use. Journal of College Student Development 38: 655-665

Szpakow, A., Stryzhak, A., \& Prokopowicz, W. (2011). Evaluation of threat of mobile phoneaddition among Belarusian University students. Prog Well-being Sci, 1(2), 96-100.

Tindell, D. R., \& Bohlander, R. W. (2012). The use and abuse of cell phones and text messaging in the classroom: A survey of college students. College Teaching, 60(1), 1-9.

Torrecillas, L. (2007). Mobile phone addiction in teenagers may cause severe psychosomatic disorder. Medical studies, 14(3), 11-13.

Torrecillas, L. (2007). Mobile phone addiction in teenagers may cause severe psychosomatic disorder. Medical studies, 14(3), 11-13.

Walsh, S. P., White, K. M., Cox, S., \& Young, R. M. (2011). Keeping in constant touch: The predictors of young Australians' mobile phone involvement. Computers in human behavior, $27(1), 333-342$.

Walsh, S. P., White, K. M., \& Young, R. M. (2008). Over-connected? A qualitative exploration of the relationship between Australian youth and their mobile phones. Journal of adolescence, 31(1), 77-92.

Wajcman, J., Bittman, M., Jones, P., Johnstone, L., \& Brown, J. (2007). The impact of the mobile phone on work/life balance. Canberra: Australian Mobile Telecommunications Association \& Australian National University.

Wajcman, J., Bittman, M., Jones, P., Johnstone, L., \& Brown, J. (2007). The impact of the mobile phone on work/life balance. Canberra: Australian Mobile Telecommunications Association \& Australian National University. 
Young, K., \& Abreu, C. (2011). Internet addiction. A handbook and guide to evaluation and treatment. Hoboken, NJ: John Wiley \& Sons.

Young, K. S., \& De Abreu, C. N. (2011). Internet addiction. A handbook and guide to evaluation.

Young, K. S. (1998). Internet addiction: The emergence of a new clinical disorder. Cyberpsychology \& behavior, 1(3), 237-244. 